412

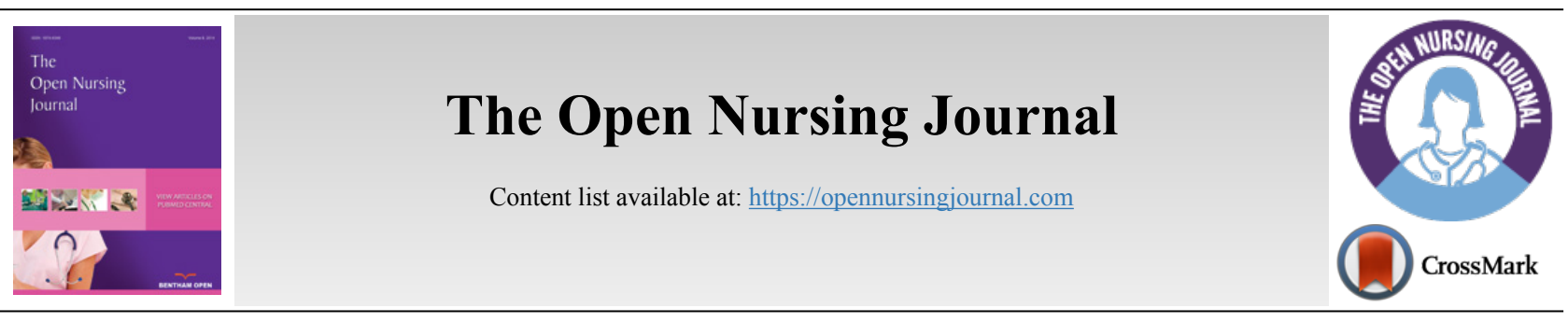

SYSTEMATIC REVIEW

\title{
A Scoping Review of Men's Health Situation in Primary Health Care
}

Cléa Conceição Leal Borges ${ }^{1}$, Anderson Reis de Sousa ${ }^{1}$, Isabella Félix Meira Araújo ${ }^{2}$, José Edward Ortiz Rodríguez ${ }^{3}$, Oscar Javier Vergara Escobar ${ }^{3, *}$, Ridalva Dias Martins ${ }^{2}$, Álvaro Pereira ${ }^{2}$ and Fernando Lannes Fernandes ${ }^{4}$

${ }^{\prime}$ Nursing School, Universidade Federal da Bahia, Salvador, Brazil

${ }^{2}$ Nursing School, Fundación Universitaria Juan N. Corpas, Bogota, Colombia

${ }^{3}$ Department of Nursing School, Universidad Nacional de Colombia, Bogota, Colombia

${ }^{4}$ School of Education and Social Work, University of Dundee, Dundee, Colombia

\begin{abstract}
:
Introduction:

There has been an increasing number of studies that have evidenced the profile of male morbidity and mortality, their causes and related consequences, and their association with the low demand and men's permanence in the services offered in Primary Health Care (PHC).

Objective:

The objective of the study was to map the literature on men's health situation in Primary Health Care.

Methods:

A scoping review, according to the Joanna Briggs Institute protocol, with the $\mathrm{PCC}$ acronym $(\mathrm{P}-\mathrm{men}, \mathrm{C}-$ health situation, $\mathrm{C}-$ in primary care), was conducted in the Medline/Pubmed, COCHRANE, Web of Science, SCOPUS, Science Direct, LILACS, BDENF, MEDCARIBE, and SciELO databases, using the descriptors "Men", "Men's Health", "Health Services Needs and Demand", "Primary Health Care" in three information sources (EBSCO, PubMed and SciELO).

Results:

Men's health situation in Primary Health Care is defined by the influence of the social construction of the masculinities and cultural aspects in the adoption of health care behaviors and practices, in the way in which men present their health complaints, demands, and needs, and establish bonds with the health professionals and the services.

\section{Conclusion:}

There is a number of sociocultural factors inherent to masculinities, institutional factors of the services' organization, and relational factors of men with the health professional that intervene together with the health situation.
\end{abstract}

Keywords: Men, Men's health, Primary health care, Health service needs, Demands, Health profession.

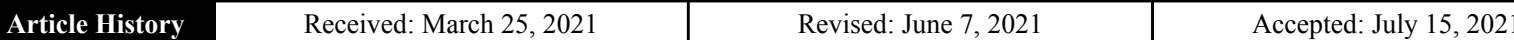

\section{INTRODUCTION}

There has been an increasing number of studies that have evidenced the profile of male morbidity and mortality, their causes and related consequences, and their association with the low demand and men's permanence in the services offered in Primary Health Care (PHC), which have drawn the attention to the problematic context existing in men's health situation in

\footnotetext{
* Address correspondence to this author at Department of Nursing School, National University of Colombia, Bogota, Colombia;

E-mail: oscar.vergara@juanncorpas.edu.co
}

several countries of the world $[1,2]$. However, few research studies have been devoted to presenting how men's health situation is configured in the PHC context, care practices, health behaviors adopted by men, complaints, demands, and health needs raised in health units and facilities that make up this care level [3 - 6].

Men are mostly more exposed to health risk situations when compared to women. This risk is seen as something to be faced and prevented in public policies, since health care can be associated with the male population's notion of frailty, 
generating concealment of male demands and needs, from a gender perspective, on the part of Primary Health Care, which does not generally focus on the male population. In this context, it is necessary to look for ways to involve men in those services due to the excess costs produced by hospital admissions [5 - 9].

In countries such as Brazil, where there is a National Policy for Comprehensive Care to Men's Health instituted by the Ministry of Health, the health situation profile of the male population has revealed that, for every three deaths of individuals aged between 20 and 53 years old, two are men and that, every five deaths of individuals aged between 20 and 30 years old, five are male. Among the main causes of morbidity are diseases of the circulatory system, chronic diseases, and neoplasms [3, 10, 11]. However, epidemiological data show few aspects related to health promotion and care practices adopted by men in PHC. In this sense, aspects related to prevention should be explored, especially external causes such as traffic and work accidents, violence, suicide, eating habits, use of alcohol and other drugs, clinical examinations, and prevention of Sexually Transmitted Infections [9 - 16].

In consonance with the aforementioned needs, the importance of recognizing the aspects that influence men's health situation in PHC is emphasized, ranging from genderrelated sociocultural factors and the social constructions of masculinities to institutional factors that arise from the problem of access, coverage of services, and care, structuring of specific care lines and networks, training and sensitization of teams of health professionals, and establishment of a culture of men's health care [14 - 18].

Thus, for these reasons, it is essential to map the scientific literature through a scoping review that is able to point out the essential markers to reveal the specificities of the scenario investigated and to signal directions for the planning and execution of actions aimed at health care and the production of men's health care. Moreover, being able to characterize the context of men's health situation from the technological density present in PHC in different geographical territories highlights the presence of potentialities and weaknesses that guide the work process in health and nursing and the inter-professional and inter-collaborative practice.

Based on the panorama presented and considering the magnitude of the scenario, which indicates the need for further research studies, this study aims at mapping, in the literature, men's health situation in Primary Health Care.

\section{METHODS}

This is a collaborative network study involving researchers from four countries: Scotland, Mexico, Colombia, and Brazil. It is a systematic literature review, of the scoping review type, in order to synthesize scientific evidence on emerging issues. The Joanna Briggs Institute protocol [19] was followed to identify eligible studies and to formulate the research question using the PCC strategy, an acronym for men (P), health situation (C), and primary health care (C).

For inclusion in this review, the studies should be primary, without time restriction, published in any language, and discussing the profile of men in health services that use primary care. Secondary studies (such as conference abstracts, conference notes, or other reviews) were excluded, as well duplicated studies.

The search strategies were elaborated in three stages. Initially, "Men" AND "Men's Health" were used in the Medical Literature Analysis and Retrieval System Online through the US National Library of Medicine (MEDLINE/PubMed) to find uncontrolled descriptors contained in the articles of interest. Subsequently, controlled descriptors, obtained from the Medical Subject Headings $(\mathrm{MeSH})$, and not controlled, obtained from the initial search, were combined with the Boolean operators "OR" and "AND". Finally, this strategy was adapted for each database (Table 1).

Table 1. Search strategies used per database. Salvador, BA Brazil, 2020.

\begin{tabular}{|c|c|c|}
\hline Database & Search Strategy & Results \\
\hline MEDLINE/PubMed & $\begin{array}{c}\text { ((“Men” OR “Mens Health” OR “Men's Health”) AND (“Health Services Needs and Demand”) AND (“Primary } \\
\text { Health Care”)). }\end{array}$ & 93 \\
\hline COCHRANE & $\begin{array}{c}\text { ((“Men” OR “Mens Health” OR “Men’s Health”) AND (“Health Services Needs and Demand”) AND (“Primary } \\
\text { Health Care”)). }\end{array}$ & 03 \\
\hline Web of Science & $\begin{array}{c}\text { (("Men" OR "Mens Health" OR "Men's Health") AND ("Health Services Needs an } \\
\text { d Demand") AND ("Primary Health Care”)) }\end{array}$ & 02 \\
\hline SCOPUS & $\begin{array}{c}\text { TITLE-ABS-KEY(((“Men” OR “Mens Health” OR “Men's Health”) AND (“Health Services Needs and Demand”) } \\
\text { AND (“Primary Health Care”))). }\end{array}$ & 87 \\
\hline Science Direct & $\begin{array}{c}\text { ((“Men” OR “Mens Health” OR “Men's Health”) AND (“Health Services Needs and Demand”) AND (“Primary } \\
\text { Health Care”)) }\end{array}$ & 13 \\
\hline LILACS & 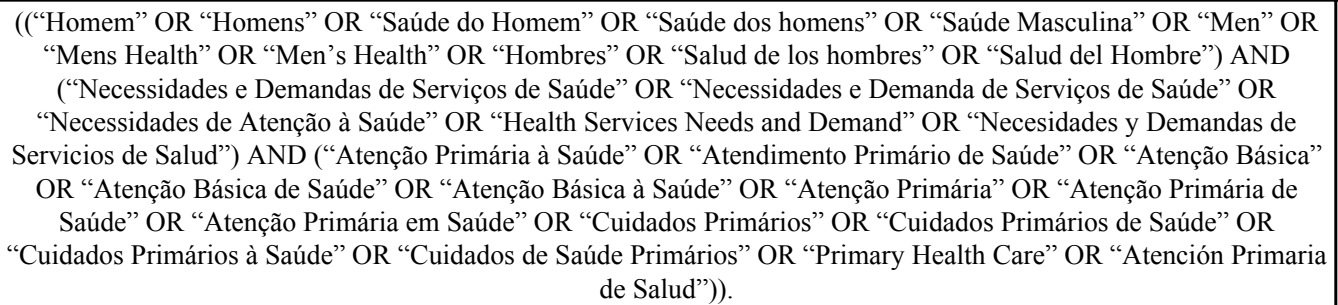 & 40 \\
\hline
\end{tabular}




\begin{tabular}{|c|c|c|}
\hline Database & Search Strategy & Results \\
\hline BDENF & 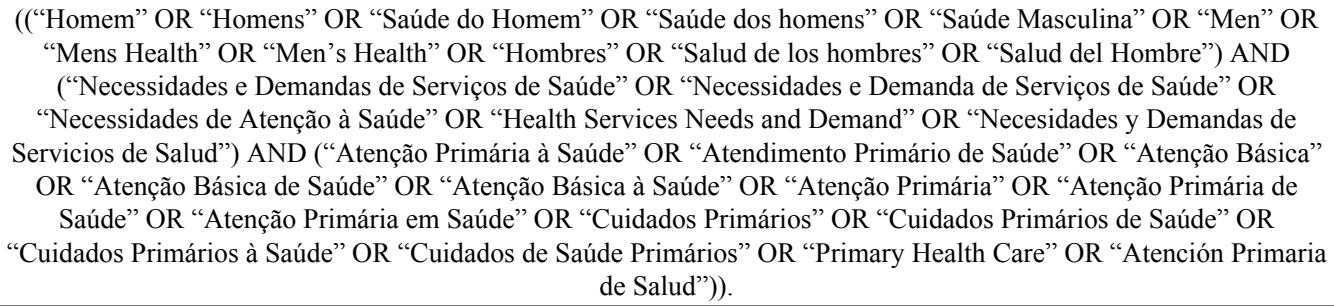 & 09 \\
\hline MEDCARIBE & 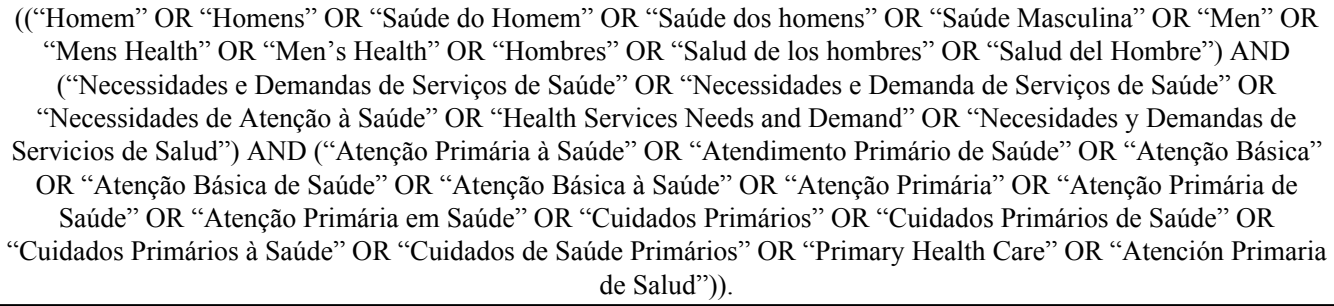 & 01 \\
\hline SciELO & $\begin{array}{c}\text { ((“homem” or "homens” or "saúde do homem”) and ("atenção básica” or "atenção primária à saúde”) and } \\
\text { ("necessidades de saúde"). }\end{array}$ & 10 \\
\hline
\end{tabular}

Search and selection of the studies that occurred between March and May 2020 were carried out by two independent reviewers, and the divergences were resolved by a third reviewer. The MEDLINE/PubMed, SCOPUS (Elsevier), Science Direct (Elsevier), and Web of Science (WOS) databases were selected, as well as the BDENF bibliographic databases specialized in the Nursing area; also the COCHRANE library, which gives access to high-quality information and systematic reviews (meta-analysis) on the effects of health interventions, and the Scientific Electronic Library Online were selected. The Scientific Electronic Library Online - SciELO covers a selected collection of Brazilian scientific journals, in addition to the Latin American and Caribbean Literature in Health Sciences (Literatura LatinoAmericana e do Caribe em Ciências da Saúde, LILACS), the main information source of the Virtual Health Library (Biblioteca Virtual em Saúde, BVS).

The studies found were exported to the EndNote ${ }^{\circledR}$ reference manager software in order to identify duplicates and gather all the publications. Moreover, the list of references was consulted in order to find additional studies. The selection of studies followed the recommendations of the Preferred Reporting Items for Systematic Reviews and Meta-Analyses extension for Scoping Reviews, known as PRISMA-ScR, which deals with a list of items that should be present in a systematic review, with or without meta-analysis (PRISMA checklist). Fig. (1) summarizes the flow of the analyses [20].

\section{RESULTS}

The scientific production on the theme selected in this review has a concentration on Brazilian publications; however, countries such as Australia, Spain, and the United Kingdom also produced on the subject matter.

Regarding the year of publication, the most expressive were 2010 and 2014, with two and three productions, respectively. The concentration of manuscripts was evidenced in the years 2000 to 2020 , which comprises a 20 -year time frame. Moreover, the journals where the most articles were published have the characteristic of being in the area of collective health/sanitary health, nursing, family and psychosocial care, and work, and focused on the area of the health specialty, namely, oncology.

As for the journals, the manuscripts published by the Brazilian Anna Nery Nursing School journal stood out, configured as the highest prevalence with $02(22.22 \%)$ and the other in the sample of this study, $01(11.11 \%)$, totaling 07 $(77.77 \%)$. The objectives proposed by the studies analyzed were mostly intended to understand the health care context in which men are inserted in the Primary Health Care context. Moreover, the most used methods in the research are based on the emerging needs of qualitative studies, from which exploratory-descriptive, ethnographic, and hermeneutic studies stand out. However, quantitative studies also comprised the sample and are prospective and cross-sectional. The population and/or sample that set up the survey participants ranged from 11 to 1,473 .

The synthesis of the characterization of the studies that were included in the scoping review is summarized in Table 2 below:

Regarding the methodology used, five articles used the qualitative methodology, two were quantitative, one was a scoping review and the other was an ethnographic research study. The analysis of the main findings of the study showed, in the productions, centrality in the survey of barriers and difficulties faced by men regarding access to services and their demand for services, as well as the hindering and intervening factors that permeate men's permanence in institutional health spaces and their adherence and continuity in the therapies instituted, such as the treatment of chronic diseases and complications.

In addition to these thematic aspects, elements of the social construction of masculinities, such as gender-related factors, were located in the health situation context of men seeking health services in PHC. Cultural aspects related to gender norms, fear of illness, and resistance in the search for health care stand out. Furthermore, men's health profile is demarcated by socially constructed behaviors, which reassert rigid and hegemonic models of masculinities. 

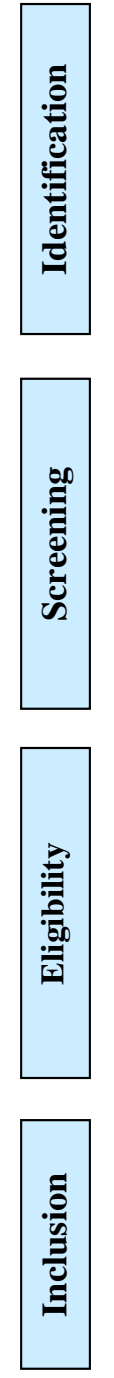
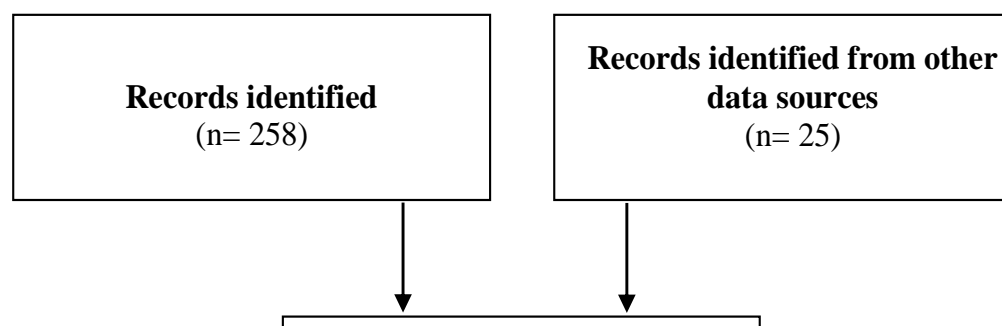
data sources

$$
(n=25)
$$

Fig. (1). Flowchart of the study selection and inclusion process. 2020.

Table 2. Characterization of the studies included in the review regarding the data collection instruments used, clinical evaluation instruments, main results, and recommendations. $(n=9)$. Salvador, BA, Brazil. 2020.

\begin{tabular}{|c|c|c|c|c|c|}
\hline \multicolumn{6}{|c|}{ Internal Variables } \\
\hline Reference & Authors (year) & Country & Journal/ Database & Method & $\begin{array}{c}\text { Population/ } \\
\text { Sample }\end{array}$ \\
\hline A1 & $\begin{array}{c}\text { Strange P, Tenni M (2012) } \\
{[21] .}\end{array}$ & Australia & $\begin{array}{l}\text { Australian Family Physician/ } \\
\text { Scopus } \\
\end{array}$ & Qualitative, descriptive & $\begin{array}{c}\text { Population } \\
(\mathrm{n}=70)\end{array}$ \\
\hline A2 & Arruda GO (2014) [22]. & Brazil & $\begin{array}{l}\text { Acta Paulista de Enfermagem/ } \\
\text { Scielo }\end{array}$ & Quantitative, cross-sectional & 421 \\
\hline A3 & $\begin{array}{l}\text { Storino LP, Ventura SK, } \\
\text { Silva KL (2013) [23]. }\end{array}$ & Brazil & Revista Anna Nery/Scopus & $\begin{array}{c}\text { Qualitative/ } \\
\text { Thematic analysis }\end{array}$ & 27 \\
\hline A4 & $\begin{array}{l}\text { Linnell S, James S (2010) } \\
\text { [24]. }\end{array}$ & England & $\begin{array}{l}\text { Community Practitioners '\& } \\
\text { Health Visitors' Association } \\
\text { Scopus }\end{array}$ & $\begin{array}{l}\text { Qualitative, with focus group } \\
\text { Content analysis }\end{array}$ & 11 \\
\hline $\mathbf{A 5}$ & \begin{tabular}{|c|} 
MIRANDA SVC de. (2020) \\
{$[25]$.} \\
\end{tabular} & Brazil & $\begin{array}{l}\text { Trabalho, Educativo e } \\
\text { Saúde/Scielo } \\
\end{array}$ & $\begin{array}{l}\text { Qualitative, with a hermeneutic- } \\
\text { dialectic approach }\end{array}$ & 41 \\
\hline A6 & Rivera CF. (2000) [26]. & Spain & $\begin{array}{c}\text { Gaceta Sanitária SESPAS/ } \\
\text { Scopus }\end{array}$ & Quantitative, prospective study & 1,473 \\
\hline A7 & $\begin{array}{l}\text { Schraiber LB et al. } \\
\text { (2010) [27]. }\end{array}$ & Brazil & $\begin{array}{c}\text { Cadernos de Saude Publica/ } \\
\text { Scopus }\end{array}$ & $\begin{array}{l}\text { Ethnographic, } \\
\text { field research }\end{array}$ & 182 \\
\hline
\end{tabular}


(Table 2) contd.....

\begin{tabular}{|c|c|c|c|c|c|}
\hline \multicolumn{6}{|c|}{ Internal Variables } \\
\hline Reference & Authors (year) & Country & Journal/ Database & Method & $\begin{array}{l}\text { Population/ } \\
\text { Sample }\end{array}$ \\
\hline A8 & $\begin{array}{l}\text { Forbat L. } \\
(2014)[28]\end{array}$ & $\begin{array}{l}\text { United } \\
\text { Kingdom }\end{array}$ & $\begin{array}{c}\text { Journal Supportive Care in Cancer/ } \\
\text { Scorpus }\end{array}$ & Scoping review & 30 \\
\hline A9 & Cavalcanti JRD (2014) [29]. & Brazil & Revista Ana Nery/Scielo & $\begin{array}{c}\text { Qualitative } \\
\text { Bardin's Content Analysis }\end{array}$ & 52 \\
\hline
\end{tabular}

Moreover, the main health demands and needs found were those related to prostate cancer, search for medications related to certain symptoms, or when they do not know how to deal with such pathological symptoms, which include febrile state, pain in general, and complications of chronic diseases. However, unawareness of the vulnerabilities to diseases by men, fear of losing their job, and the cultural condition of main family providers still prevail as barriers found in the health care of the groups surveyed.

As for the recommendations raised in the studies to improve men's health scenario in PHC, actions and strategies aiming to break the cycle of invisibility of the male population are proposed. Table 3 shows the synthesis of the selected studies, presenting the instruments for data collection and clinical evaluation, main results, and recommendations.

Table 3. Main results of the studies. Salvador, BA, Brazil. 2020.

\begin{tabular}{|c|c|c|}
\hline \multicolumn{3}{|c|}{ External Variables } \\
\hline $\begin{array}{c}\text { Data Collection Instruments } \\
\text { used }\end{array}$ & Main Results & Recommendations \\
\hline $\begin{array}{l}\text { A1: Semi-structured interview. } \\
\text { Analysis with reference to graph } \\
\text { analysis [21]. }\end{array}$ & $\begin{array}{c}\text { Men's easy access and demand for health services and primary care } \\
\text { were evidenced by the establishment of relationships among spouses } \\
\text { and friends. The establishment of clinical diagnoses performed by } \\
\text { professionals in the services also promoted practicalities in health care } \\
\text { promotion. }\end{array}$ & $\begin{array}{l}\text { - To deepen research studies on } \\
\text { interpersonal relationships, including } \\
\text { partnerships and social networks. } \\
\text { - To identify and access men at higher } \\
\text { risk for the development of prostate } \\
\text { cancer. To expand the knowledge about } \\
\text { the traditional routes resorted to by men } \\
\text { in the search for health care, for } \\
\text { opportunist health promotion actions. }\end{array}$ \\
\hline $\begin{array}{l}\text { A2: Population-based household } \\
\text { survey. } \\
\text { Use of the Brazilian Economic } \\
\text { Classification Criterion of the } \\
\text { Brazilian Association of Research } \\
\text { Companies. } \\
\text { Multiple analysis using } \\
\text { unconditioned Multiple Logistic } \\
\text { Regression Models. Application } \\
\text { of the Forwards method [22]. }\end{array}$ & $\begin{array}{l}\text { Social markers such as race/skin color, having partners and children, } \\
\text { professing religions, having complete secondary education, being } \\
\text { inserted in the labor market, having an income between } 2.1 \text { and } 4 \\
\text { minimum wages, being employers/autonomous workers, without health } \\
\text { insurance, and being included in economic class B were relevant for the } \\
\text { analysis of the health situation. } \\
\text { Self-perceived fair/poor health and the presence of reported morbidity } \\
\text { were found among the male population. However, age between } 30 \text { and } \\
39 \text { years old, elementary schooling, unemployed occupational status, } \\
\text { economic class, work, family income, skin color, health insurance, and } \\
\text { religion were important factors to be considered in men's health } \\
\text { situation. Economic class was an important factor for self-perceived } \\
\text { health. On the other hand, white-skinned men presented higher } \\
\text { morbidity, as well as those aged from } 40 \text { to } 49 \text { years old and from } 50 \text { to } \\
59 \text { years old, retired or on medical leave. }\end{array}$ & $\begin{array}{l}\text { - To align self-perceived health with } \\
\text { sociodemographic indicators and with } \\
\text { the characteristics that condition } \\
\text { socialization of men's needs with a } \\
\text { focus on directing care for adults. }\end{array}$ \\
\hline $\begin{array}{l}\text { A3: Semi-structured interview, } \\
\text { using a recorder. Bardin's content } \\
\text { analysis [23]. }\end{array}$ & $\begin{array}{c}\text { The men who most sought the health service in Primary Care had a } \\
\text { profile of } 42-62 \text { years old and low schooling. The main health } \\
\text { demands were directed to the prevention of prostate cancer. The fear of } \\
\text { detecting a serious disease permeated men's health complaints regarding } \\
\text { perceived health and disease. The responsibility of being the family } \\
\text { provider, added to the non-recognition of individual vulnerabilities, has } \\
\text { affected the need for health care. }\end{array}$ & $\begin{array}{c}\text { - To embrace and create the promotion } \\
\text { of bonds between service professionals } \\
\text { and men throughout the health system. } \\
\text { To break with the invisibility of the } \\
\text { male population. } \\
\text { - To give views to the principles of } \\
\text { equality and care integrality. }\end{array}$ \\
\hline $\begin{array}{l}\text { A4: Semi-structured interview } \\
\text { until reaching data saturation and } \\
\text { records in a field diary. Use of the } \\
\text { Taxonomy of Health Needs under } \\
\text { thematic content analysis [24]. }\end{array}$ & $\begin{array}{l}\text { Despite recognizing their health needs, men do not acknowledge their } \\
\text { vulnerabilities, do not find themselves responsible for self-care, and, } \\
\text { even if they need the service, this will not be able to solve their needs. } \\
\text { Despite presenting severe chronic diseases, such as diabetes and } \\
\text { hypertension, men refused to undergo the proposed treatments. } \\
\text { However, they showed that they had built bonds with the health } \\
\text { professionals of the service. }\end{array}$ & $\begin{array}{l}\text { - It is indicated to promote the } \\
\text { elaboration of health practices that are } \\
\text { more efficient in identifying and } \\
\text { interpreting health needs } \\
\text { - To create welcoming and bonding } \\
\text { possibilities for men throughout the } \\
\text { health system. }\end{array}$ \\
\hline
\end{tabular}


(Table 3) contd.....

\begin{tabular}{|c|c|c|}
\hline \multicolumn{3}{|c|}{ External Variables } \\
\hline $\begin{array}{c}\text { Data Collection Instruments } \\
\text { used }\end{array}$ & Main Results & Recommendations \\
\hline $\begin{array}{l}\text { A5: In-depth individual } \\
\text { interviews, collection of } \\
\text { information in the interviewees' } \\
\text { medical records and records in a } \\
\text { field diary. Analysis based on } \\
\text { interpretation levels [25]. }\end{array}$ & $\begin{array}{c}\text { Low visibility of rural men was evidenced in the performance of health } \\
\text { professionals working in the PHC service. In the health context of rural } \\
\text { workers, satisfaction with medications goes beyond their supply. There } \\
\text { was an increase in the variety of medication use. The male population } \\
\text { investigated presented the following health needs: physiotherapy, access } \\
\text { to the tuberculosis and leprosy detection and treatment program, and } \\
\text { mental health care devices. The search for health services by rural } \\
\text { workers was centralized in the performance of the prostate evaluation } \\
\text { test. }\end{array}$ & $\begin{array}{l}\text { - To promote changes in the behavior } \\
\text { of professionals who are part of PHC } \\
\text { teams and, mainly, of family health } \\
\text { teams in the field. }\end{array}$ \\
\hline $\begin{array}{l}\text { A6: Consultation of medical } \\
\text { records; statistical tests; data } \\
\text { processing in the SPSS } 7.5 \\
\quad \text { software [26]. }\end{array}$ & $\begin{array}{l}\text { Most men are young, did not return to the service for continuity of the } \\
\text { health therapy instituted, and did not have diagnoses of diseases and/or } \\
\text { confirmed complications. } \\
\text { Low frequency and consultations with health professionals in the } \\
\text { service was evidenced. }\end{array}$ & $\begin{array}{c}\text { - To explore those data more broadly, } \\
\text { in other populations and with a greater } \\
\text { number of physicians involved. }\end{array}$ \\
\hline $\begin{array}{l}\text { A7: Ethnographic observations, } \\
\text { semi-structured interviews with } \\
\text { users and professionals, and } \\
\text { hermeneutic-dialectical analysis } \\
\text { [27]. }\end{array}$ & $\begin{array}{l}\text { Men claim that they prefer to delay their search for care as much as } \\
\text { possible and only do so when they can no longer cope with their dental } \\
\text { pain symptoms. Factors preventing them from resorting to the service } \\
\text { were raised, namely: being at work; lack of time; fear of losing their } \\
\text { jobs; difficult access; and service operation. They think that care should } \\
\text { be quick and punctual, thus giving priority to hospitals and emergency } \\
\text { services. The men revealed weaknesses in the service: lack of } \\
\text { professionals and frequent postponement of consultations or exams; } \\
\text { absence of a urologist, who seems to be the most appropriate } \\
\text { professional for them; lack of medications or other resources; and low } \\
\text { care quality. The users avoid the PHC service because they do not know } \\
\text { how to deal with some situations related to alcohol or drug abuse, urban } \\
\text { or domestic violence, or psychological distress/diseases. The complaints } \\
\text { most mentioned by the men were as follows: pain, fever, contusions and } \\
\text { injuries, chronic diseases such as hypertension and diabetes, and dental } \\
\text { treatment. }\end{array}$ & $\begin{array}{l}\text { - To strengthen care production } \\
\text { regarding the requalification of its } \\
\text { comprehensive and care response, } \\
\text { because the complexity of primary care } \\
\text { is not superimposed on that of } \\
\text { pathologies, and should be } \\
\text { reconstructed as care production even } \\
\text { to deconstruct medicalization with } \\
\text { users as the only and best reading of } \\
\text { health needs. } \\
\text { - To expand scientific production on } \\
\text { the subject matter, to enrich the debate. }\end{array}$ \\
\hline $\begin{array}{l}\text { A8: Questionnaire and focus } \\
\text { group with men. Content analysis } \\
{[28] .}\end{array}$ & $\begin{array}{l}\text { The men who participated in a health education group in the PHC } \\
\text { service showed that they believed that health care was a female role. } \\
\text { Those men who live in needy communities reported having access to the } \\
\text { health service and considered it friendly. Living close to the service } \\
\text { contributed to men's participation in the actions offered, such as } \\
\text { educational groups. Changes in long-term lifestyle only occurred } \\
\text { through men's self-perception regarding practical health benefits. The } \\
\text { fear of presenting symptoms of diseases influenced the non-search for } \\
\text { the health service in PHC. Feminization in the health service } \\
\text { environment in PHC was raised as a complicating factor for the male } \\
\text { presence in this scenario. The men identified that it was important to } \\
\text { adopt an approach that did not automatically attribute the guilt of all } \\
\text { health problems to the individual's behavior, for example: being a } \\
\text { smoker. }\end{array}$ & $\begin{array}{l}\text { - To establish the creation of conditions } \\
\text { to attract the male population and } \\
\text { involve them in the service. } \\
\text { - To recognize the limitations or } \\
\text { barriers of the health services that are } \\
\text { fundamental for health professionals } \\
\text { and the provision of individualized } \\
\text { services, and the use of people-centered } \\
\text { care models can be a strategy that } \\
\text { enables health promotion and disease } \\
\text { prevention in care. }\end{array}$ \\
\hline $\begin{array}{l}\text { A9: Application of a semi- } \\
\text { structured interview and phone } \\
\text { contact - Enterprise Data } \\
\text { Warehouse [29]. }\end{array}$ & $\begin{array}{l}\text { Men do not always act on the basis of knowledge about the risk of being } \\
\text { ill. In this context, the partners and friends from social networks serve to } \\
\text { mediate the interpretation of this risk. Health behavior is a way to } \\
\text { represent more open forms of masculinities. } \\
\text { If partners are positioned as responsible for men's health, then this can } \\
\text { undermine advances in these men's own responsibility for their well- } \\
\text { being and add burdens to women. } \\
\text { Men who have successfully navigated and accessed health care face } \\
\text { hegemonic masculinities (they can avoid seeking help or talking about } \\
\text { physical and sexual frailty). } \\
\text { Cancer diagnosis was considered as a catalyst for the discussion of } \\
\text { potential signs and symptoms and for encouraging help-seeking } \\
\text { behaviors, since many men indicated that, before their own diagnosis, } \\
\text { they did not routinely talk about the risk of prostate cancer or about } \\
\text { other types of cancers. } \\
\text { After cancer diagnosis, men can take a more open and direct approach } \\
\text { to discuss intimate issues such as urinary flow and greater risk sensation } \\
\text { with friends, social networks and family. } \\
\text { They actively engage, both proactively and reactively, in talking about } \\
\text { prostate cancer and encouraging others to be "aware of symptoms" and } \\
\text { seek counseling and testing in primary care services. }\end{array}$ & $\begin{array}{l}\text { - To recruit men's partners as allies in } \\
\text { health promotion. } \\
\text { - To expand knowledge about } \\
\text { relationships beyond traditional routes. } \\
\text { - To facilitate interpersonal relationship } \\
\text { channels as a way to ensure access to } \\
\text { men at higher risk of prostate cancer. } \\
\text { - To ensure the safe provision of health } \\
\text { information to men and avoid sharing } \\
\text { misleading and inaccurate advice. } \\
\text { - To promote health. } \\
\text { - For men, it is difficult to talk about } \\
\text { their health conditions, especially if } \\
\text { they are related to their sexuality, such } \\
\text { as cancer, which, in addition to being a } \\
\text { chronic disease, is a stressful situation } \\
\text { and, if there is no stable social support, } \\
\text { generates frustration and inadequate } \\
\text { management of one's own health. }\end{array}$ \\
\hline
\end{tabular}




\section{DISCUSSION}

In view of the above, it is understood that men's inclusion in primary health care is a challenge proposed to the public policies due to the factors that combine in the way male populations have usually conceived health, in the way professionals produce health care for men, and in the way managers and public authorities recognize the health needs of this population. Men's health situation in Primary Care is permeated by specific circumstances and barriers, which are sometimes complex, sometimes singular, and permeate the health context to be observed. Human health has aroused interest in Brazilian health systems, in the case of Latin America today and in other countries such as Ireland and Australia. These countries have heard that alternative narratives based on strengths about boys and men are an important health promotion strategy to influence the improvement of health outcomes for men and women [30]. Access practicalities are also observed in the findings, revealing opportunities in the insertion of existing men's health care devices and technologies at the primary care level. However, the studies selected have largely explained the presence of factors that hinder, prevent, and exclude men from the services and consequently generate harmful implications for men's health situation, such as late recognition of diseases and complications. Therefore, health communication actions need to be more valued and effective in reaching and sensitizing men towards $\mathrm{PHC}$, with a potential aggregating factor in improving the visibility of this health care level.

Moreover, social markers influence the men's health situation identified in the PHC service network based on the results found in the studies. Recent epidemiological studies have indicated that men are exposed to increased health risks due to biological and social factors [31]. It is relevant to pay attention to variables with structuring dimensions such as age and generation, schooling, race/skin color, social class, employment situation, employability, and religion, as well as those that demarcate relationships with men's health situation.

In view of this, data collected by the Brazilian Ministry of Health showed that men aged between 20 and 59 years old present higher morbidity and mortality rates when compared to women in the same age group. Furthermore, they are often more involved in most cases of violence, hardly seek PHC, and are more exposed to traffic incidents and to licit and illicit drugs, among other factors. These aspects are directly related to the sociodemographic, economic, educational, political, territorial, and cultural profiles that men present and are involved in [18, 32, 33].

In line with the social markers highlighted above is the additional fact that the social construction of masculinities proved to be influential in men's health situation in the context of PHC. Among male populations, the exacerbation of attributes considered typical of men has been observed, such as virility, strength, honor, power, and feeling of invulnerability, which, to a large extent, promote the distancing of those men from the health service and perpetuate self-healing practices and self-medication $[8,32,33]$.

In a society that levels power, success, and strength as male characteristics, men seek, in the process of socialization, to distance themselves from characteristics related to the feminine: sensitivity, care, dependence, and fragility. These distinct attributions between men and women often result in behaviors that predispose them to diseases, complications, and death. The most common is that married men need their companions in health care, turning marriage into a protective factor against a series of diseases, which is not the case for women [14, 26, 34, 35]. However, in the studies investigated, it was not possible to gather information on the health situation of gay, bisexual and transgender men, which reveals a limiting factor in relation to the category of sexual and gender identity.

A notorious aspect of men's health situation in PHC is the perception of their health in relation to the prevention of diseases, especially prostate cancer, and the biological, biomedical and curative nature, which still permeates the production of self-care that influences men's health behavior, as seen in the findings of studies that revealed the strong inclination of men towards self-medication. It is relevant to overcome approaches focused on complaints, prescriptive approaches, and symptomatology to achieve a comprehensive approach to men's health situation [36].

When satisfactory, men's health situation has the potential to contribute to adherence to the services offered in PHC. In this sense, it is relevant to develop actions that increase men's awareness of health care, as well as their visibility in PHC, in order to ensure the overcoming of stereotypes and intervening factors preventing male access to services [37 - 41].

This study evidenced that factors such as fear of illness, being the family provider, presenting a sense of invulnerability, and recognizing health services as feminized spaces, can strengthen male distancing from PHC.

Determinants related to self-care, which encompass the difficulties in recognizing and accepting their frailties, can contribute to men's reduced access to health services, usually performed only when the symptom or health problem has already been installed $[42,43]$. Men's inclusion in primary care services is a challenging issue because, in general, campaigns prioritize children, women, and older adults, with little emphasis on men's health care. Thus, professional health teams, such as nursing teams, need to be vigilant so that health interventions can be addressed in order to contemplate those factors so that it is possible to strengthen the culture of men's health care in PHC [35]. This resurgence of the male culture definitely should be important for health systems, services, nursing, and health professionals, respecting values, feelings, and gender equality policies.

In this study, it was possible to understand that the health needs found in the studies based on the research carried out with men using the PHC services presented greater predominance of dental health, the control of neglected diseases and Non-Communicable Chronic Diseases (NCCD), pain, musculoskeletal problems, control of clinical symptoms fever, sexual health, and mental health. These results illustrate the characterization, although limited, of men's health situation at this health care level and expose the limitations existing in the studies in presenting, in a robust and more detailed way, 
how the configuration of this panorama occurs.

It is worth noting that it is necessary to pay attention to the way in which intersectionality occurs in men's health situation in PHC, allowing for the prior and qualified recognition of how such variables intersect, as they influence men's health care practices, in access to services, adherence to and continuity of therapies and, consequently, in the formulation of inequalities and vulnerabilities or in the safety and survival of the male population, with a view to improving the individual and collective health situation [44 - 47].

The intersectional approach, in turn, assesses that no difference should be reduced to a single classification system, with the intention of not submerging the strength of the articulation it proposes for social markers, in order to grasp the multiple dimensions of inequalities that access and influence the social positions, the experiences of the subjects and the male power relations that constitute, for example, a patriarchal society [46, 47].

Other focuses of men's health situation, in addition to control of diseases and specific complications of this key population, need to be taken into account in the provision of care in PHC, so that greater emphasis is directed to health promotion. From this perspective, it is essential that singularities, specificities, health needs and demands be raised among the male population [47].

The dissemination of health data and information, such as the formulation of specific indicators that reveal men's health situation, is extremely relevant for the advancement in the development and structuring of public health policies, such as focal health policies for the male population $[46,47]$.

It is worth mentioning that the male approach in the Nursing consultation can contribute to the identification of risk factors, signs, and symptoms of probable changes that motivate these men to perform the screening test and consequent prevention [13, 32, 35, 41].

Although there is a growing understanding of gender divergences regarding health demands and needs and an increase in men's health promotion actions, there are still significant gaps to be filled, from the adequacy of the structure/ambiance for welcoming in PHC to the development of strategies for prevention, treatment, and recovery of complications in this population [34, 41].

Regarding this, a review study revealed that, although greater awareness and commitment of health professionals was observed over the years to strengthen health actions directed to male demands and needs, they prove to face structural, governmental, financial, and cultural difficulties and limitations in care management and men's health promotion $[32,45]$.

Although the results have shown that men's attendance to PHC consultations is low and that they present difficulties in complying with the therapies as well as with the treatments instituted by health professionals in the services, positive aspects were observed, such as the establishment of a bond between the male population and the service professionals, participation in health educational groups and change in lifestyle, perceived from the health care stimulated in PHC [35, 42, 45 - 49].

It is essential that men have a notion of the importance of being followed up in PHC near their residence, attending the consultation with the nurse, who will provide guidelines in relation to the promotion of their health, listening and elucidating the doubts that arise during follow-up. This professional is responsible for designing actions to attract men to the health system. In this way, they can continuously improve to meet the needs of this population better, create space for those users and an exclusive group to discuss men's health, manage strategies that avoid queues, perform home visits, and generate comprehensive care $[13,35,43]$.

Great practices can be performed by avoiding delays in scheduling appointments and exams that may end up demotivating and even distancing men from PHC. The value of health education as an activity that can strengthen men's bond with the health services is emphasized, avoiding care only in emergencies, leading them to think of prevention as a response in health education [47, 50 - 53]. The creation of a group of men who seek to sensitize the male population of productive age about the importance of disease prevention to avoid developing avoidable complications [14, 16, 54 - 56]. Another practice that has been used in the UK and Australia is social networks, as a new way of relating, through the exchange of personal information within certain social groups, which go beyond traditional routes, but which can be a powerful channel and can serve as effective mechanisms to identify and access men in PHC [23, 37, 40, 57 - 59].

Therefore, it is emphasized that the understanding of institutional and sociocultural obstacles is indispensable for the proposal of planning joint actions to promote men's access to primary care services and thus contribute to equality in health and to a reduction in male morbidity and mortality rates.

The results found in the studies may stimulate future research, contributing to discussions, reflections, and new strategies of public policies in men's health in primary health care services for Brazil and Latin America.

\section{CONCLUSION}

The men's health situation evidenced by Primary Health Care professionals involved dimensions of care and of men's health behavior, which reflect the social construction of masculinities, of the culture, and of the relationship of men with the health services and professionals, in addition to the dimension regarding the emergence of health and disease demands and needs, expressed by means of lower-complexity acute symptom complaints and chronic physical and sexual health problems, in addition to mental health.

A number of complementary factors proved to intervene in men's health situation, in the institutional and organizational nature of the health services, namely: the presence of barriers and difficulties in accessing the health services, resistance to seek the health service and in adherence to the therapies, and weaknesses in men's permanence and observance of the health actions and services offered in Primary Care. In addition to that, individual factors were also found: presenting a low health 
perception, fear of being ill, feeling invulnerable, selfmedicating, perceiving health units as feminine, scarcely resolute and with low visibility, not attending previously scheduled appointments with health professionals, being family providers and, for this reason, not recognizing the possibilities to care for their own health and seek available institutional services in Primary Health Care. However, they do participate in health educational groups at this care level investigated.

\section{CONSENT FOR PUBLICATION}

Not applicable.

\section{FUNDING}

None.

\section{CONFLICTS OF INTEREST}

The authors declare no conflict of interest, financial or otherwise.

\section{ACKNOWLEDGEMENTS}

Declared none.

\section{REFERENCES}

[1] Brasil. Ministério da Saúde. National Policy for Comprehensive Care to Men's Health: Brasília National Action Plan 2009. Available from: http://portalsaude.saude.gov.br/images/pdf/2014/maio/21/CNSH-DOC -Plano-Nacional.PNAISH-2009-2011.pdf

[2] Griffith DM, Gilbert KL, Bruce MA, Thorpe RJ. Masculinity in men's health: barrier or portal to healthcare?Men's health in primary care. Cham: Humana Press 2016; pp. 19-31.

[http://dx.doi.org/10.1007/978-3-319-26091-4_2]

[3] Beltrán-Sánchez H, Finch CE, Crimmins EM. Twentieth century surge of excess adult male mortality. National academy of sciences 2015; 112(29): 8993-8

[http://dx.doi.org/10.1073/pnas.1421942112]

[4] Martins ERC, Medeiros AS, Oliveira KL, Fassarella LG, et al. Vulnerability of young men and their health needs. Anna Nery School 2020; 24(1): e20190203.

[http://dx.doi.org/10.1590/2177-9465-ean-2019-0203]

[5] Fadich A, Llamas RP, Giorgianni S, Stephenson C, Nwaiwu C. 2016 Survey of state-level health resources for men and boys: Identification of an inadvertent and remediable service and health disparity. Am J Men Health 2018; 12(4): 1131-7.

[http://dx.doi.org/10.1177/1557988318763643] [PMID: 29577837]

[6] Nunes Moreira MC, Gomes R, Ribeiro CR. " Are men coming to the clinic now?!" Healthcare strategies for men. Cadernos de Saude Publica 2016; 32(4)

[http://dx.doi.org/10.1590/0102-311X00060015] [PMID: 27167044]

[7] Sousa AR, Oliveira JA, Almeida MS, Pereira Á, Almeida ES, Vergara Escobar OJ. Implementation of the National Policy for Comprehensive Attention to Men's Health: challenges experienced by nurses. Rev Esc Enferm USP 2021; 55: e03759.

[http://dx.doi.org/10.1590/s1980-220x2020023603759] [PMID: 34287486]

[8] Sousa AR, Queiroz RM, Florêncio RMS, Portela PP, et al. Men in primary health care services: repercussions of construction of masculinities. Bahian Nursing Magazine 2016; 30(3): 1-10 [http://dx.doi.org/10.18471/rbe.v30i3.16054]

[9] Magalhães J, Silva RL. Perception of the current health scenario of the man: difficulties encountered by male individuals in continuous monitoring of blood pressure and diabetes in the search for health care in Cáceres-MT. Science and Studies Magazine Medical Students at UEMT - UNEMAT (Cáceres) 2015; 1(3): 39-56.

[10] Lírio JGS, et al. Intra-familial childhood abuse of men in criminal process. Acta Paul Enferm 2018; 31(4): 423-9.

[http://dx.doi.org/10.1590/1982-0194201800059]

[11] Tipos de câncer 2019. Available from: https://www.inca.gov.br/tipos-de-cancer. Acesso em: 05.01.2021
[12] Hemmi AP, Baptista TW, Rezende MD. The National Men's Health policy making process. Physis: Revista de Saúde Coletiva 2020; 30(3): $1-28$.

[http://dx.doi.org/10.1590/s0103-73312020300321]

[13] da Silva JF, dos Santos Silva K, Barbosa DF, et al. Prostate cancer with emphasis on preventive health of the men. Braz J Develop 2020; 6(10): 74532-49.

[http://dx.doi.org/10.34117/bjdv6n10-034]

[14] Vieira UA, de Oliveira Araujo M, et al. Nurses' perception of men's (non) search for Primary Health Care. Revista de Saúde Coletiva da UEFS 2020; 10(1): 58-66.

[http://dx.doi.org/10.13102/rscdauefs.v10.5454]

[15] Palmeira SS, Pereira TM, Almeida TL, Sousa AR, Alencar DC. Resolvability of services offered in the family health strategy: speech of men. Health in Networks 2018; 4(4): 105-17.

[http://dx.doi.org/10.18310/2446-4813.2018v4n4p105-117]

[16] Bacelar AYS, Coni DGL, Santos DV, et al. Men in the unit of family health. Rev enferm UFPE on line 2018; 12(19): 2507-13.

[17] Oliveira JA, Araújo IFM, Silva GTR, et al. Strategies and skills of nurses in men's health care: an integrative review. Rev Bras Enferm 2020; 73(6)

[PMID: 32901734]

[18] Ministry of Health. Profile of male morbidity and mortality in Brazil Brasilia.

2018.https://portalarquivos.2saude.gov.br/images/pdf/2018/novembro/ 07/Perfil-da-mortalidade-masculina-no-Brasil.pdf

[19] Briggs J. The Joanna Briggs Institute Reviewers Manual. Austrália: Supplement. 2015.

[20] Galvão TF, Pansani TSA, Harrad D. Top items to report Systematic Reviews and Meta-Analyses: The PRISMA Recommendation. 2015; 24(2)

[http://dx.doi.org/10.5123/S1679-49742015000200017]

[21] Arruda GO, Corrêa ACP, Marcon SS. Factors associated with indicators of health needs of adult men. Acta Paul Enferm 2014; 27 [http://dx.doi.org/10.1590/1982-0194201400091]

[22] Cavalcanti JD, Ferreira JD, Henriques AH, et al. Comprehensive Men's Health Care: needs, obstacles and coping strategies. Escola Anna Nery 2014; 18: 628-34.

[http://dx.doi.org/10.5935/1414-8145.20140089]

[23] Forbat L, Place M, Hubbard G, Leung H, Kelly D. The role of interpersonal relationships in men's attendance in primary care: qualitative findings in a cohort of men with prostate cancer. Support Care Cancer 2014; 22(2): 409-15. [doi: 10.1007/s00520-013-1989-y]. [http://dx.doi.org/10.1007/s00520-013-1989-y] [PMID: 24197054]

[24] Miranda SV, Oliveira PS, Moraes VC, et al. Needs and demands of male rural workers regarding primary health care. Trabalho, Educação e Saúde 2020; 18(1)

[http://dx.doi.org/10.1590/1981-7746-sol00228]

[25] Casares FR, Mayordomo AI, Benavent AO, et al. Characteristics of patients who do not use primary care services. Gac Sanit 2000; 14(2): 117-21.

[http://dx.doi.org/10.1016/S0213-9111(00)71444-0]

[PMID: 10804101]

[26] Schraiber LB, Figueiredo Wdos S, Gomes R, et al. Needs of health and masculinities: primary care in men's care. Cad Saude Publica 2010; 26(5): 961-70.

[http://dx.doi.org/10.1590/S0102-311X2010000500018] [PMID: 20563396]

[27] Linnell S, James S. Involving men in targeted primary health care: men's health MOTs. Community practitioner: the journal of the Community Practitioners' \&amp; Health Visitors'. Association 2010; 83(5): 31-4. [https://pubmed.ncbi.nlm.nih.gov/20503792/].

[28] Storino LP, Souza KV, Silva Kl. Men's health needs in primary care: welcoming and bonding as enhancers of completeness. Esc Anna Nery 2013; 17(4)

[http://dx.doi.org/10.5935/1414-8145.20130006]

[29] Strange P, Tenni M. Bendigo CHS Men's Health Clinic - improving access to primary care. Aust Fam Physician 2012; 41(9): 731-3. [https://search.informit.org/doi/10.3316/INFORMIT.73770620682274 5]. [PMID: 22962655]

[30] Smith JA, Watkins DC, Griffith DM. Equity, gender and health: New directions for global men's health promotion. Health Promot J Austr 2020; 31(2): 161-5. [doi:ezproxy.unal.edu.co/10.1002/hpja.337]. [http://dx.doi.org/10.1002/hpja.337] [PMID: 32242644]

[31] Park Byoungjin, Lee Yong-Jae. The next society of aging and the health of the hombres: a focus on them clinical implications of 
exercise and lifestyle modification. World J Mens Health 2020; 38.1: 24.

[32] Moreira RLSF, Fontes WD, Barbosa TM. Difficulties in inserting the men in primary health care: the nurses' speech. Esc Anna Nery 2014; 18(4): 615-21.

[33] Firmino M, Moura GG. The health of men and their perception of public health system: UBSF and public service male in the new neighborhood, Uberlândia/MG. Brazilian Magazine of Medical Geography and Health MG 2020; 16: 105-20. [http://dx.doi.org/10.14393/Hygeia16053468]

[34] Silveira CLG, Melo VFC, de, Barreto AJR. Health care of the men in primary health care: an integrative review. Rev enferm UFPE 2017; 11(3): 1528-9

[35] Vaz CAM, Souza GB, Moraes-Filho IM, Santos OP, Cavalcante MMFP. Cavalcante MMFP. Nurses' contributions to men's health in primary care. Rev Inic Cient e Ext Dez 2018; 1(2): 122-6.

[36] Cardos DV, Amorim DS, Robles AJM, Rangel TLV. The invisibility of men in primary health care units in Brazil from according to studies carried out in the last ten years. Society FACIG Science and Technology 2018; 4.

[37] Valentim de Sousa DHA, Souza de Lima MA, Vieira KFL, Saldanha AAW. Men and health care practices. G\&D 2015; 4(1) Available from: https://periodicos.ufpb.br/index.php/ged/article/view/22693

[38] Gomes R, Nascimento EF, Araújo FCA. Why men seek less health services than women? The explanations of men with low education and men with higher education. Cad Public Health 2007; 23(3): $565-74$

[http://dx.doi.org/10.1590/S0102-311X2007000300015] [PMID: 17334571]

[39] Gomes R, Granja GEMS, Honorato EJS, Riscado JLS. Bodies men in the field of health. Public Health Science, Rio de Janeiro 2014; 19(01) [http://dx.doi.org/10.1590/1413-81232014191.0579]

[40] Silveira CLG, Melo VFCD, Barreto AJR. Men's health care in primary health care: an integrative review. Rev sick UFPE 2017; 11(3): 1528-35.

[41] Cesaro BCD, Santos HBD, Silva FNMD. Masculinities inherent to Brazilian policy on men's health. Rev Panama Salud Publica 2018; 42(119)

[http://dx.doi.org/10.26633/RPSP.2018.119]

[42] Oliveira ED, Couto MT, Separavich MAA, Luiz ODC. Contribution of intersectionality in understanding the health-disease-care of young men in urban poverty contexts. Interface Commun Health Edu 2020; 24: e180736.

[http://dx.doi.org/10.1590/interface.180736]

[43] Hankivsky O, Reid C, Cormier R, et al. Exploring the promises of intersectionality for advancing women's health research. Int J Equity Health 2010; 9(1): 5 . [https://equityhealthj.biomedcentral.com/articles/10.1186/1475-9276-9 $-5]$.

[http://dx.doi.org/10.1186/1475-9276-9-5] [PMID: 20181225]

[44] Bauer GR. Incorporating intersectionality theory into population health research methodology: challenges and the potential to advance health equity. Soc Sci Med 2014; 110: 10-7.

[http://dx.doi.org/10.1016/j.socscimed.2014.03.022] [PMID: 24704889]
[45] Strategies and skills of nurses in men's health care: integrative review. Rev Bras Enferm 2020; 73(6)

[PMID: 32901734]

[46] Men's health care under the Strategy Family Health. Collective Health Science 2014; 9(2): 429-38.

[http://dx.doi.org/10.1590/1413-81232014192.05802013]

[47] Schraiber LB, Gomes R, Couto MT. Men and health on the agenda of Public Health. Science Health Collect 2015; 1(10): 7-17.

[http://dx.doi.org/10.1590/S1413-81232005000100002]

[48] Barrosa CT, Gontijo DT, Lyra J, Lima LS, Monteiro EMLM. "If the man takes care of his own health, it will seem contradictory to the work": the relation between masculinities and health care for young men in vocational training. Saude Soc 2018; (27): 2-, 423-434. [http://dx.doi.org/10.1590/S0104-12902018166057]

[49] Costa GLH, Oliveira CN, Nascimento BCMC. Self care and men's illness: a national integrative review. Rev Psicol Saúde 2019; 11(3): 19-33.

[http://dx.doi.org/10.20435/pssa.v11i3.933]

[50] Pimentel WC, Vasconcelos ICBL, Ribeiro RRS, et al. Evaluation of the men's health policy in the primary care in a city in the agreste of Pernambuco. Braz J Hea Rev 2020; 3(3): 3935-47. [http://dx.doi.org/10.34119/bjhrv3n3-003]

[51] O'Brien AP, Hurley J, Linsley P, McNeil KA, Fletcher R, Aitken JR. Men's Preconception Health: A Primary Health-Care Viewpoint. Am J Men Health 2018; 12(5): 1575-81.

[http://dx.doi.org/10.1177/1557988318776513] [PMID: 29774805]

[52] Lovett D, Rasmussen B, Holden C, Livingston PM. Are nurses meeting the needs of men in primary care? Aust J Prim Health 2017; 23(4): 319-22.

[http://dx.doi.org/10.1071/PY16106] [PMID: 28747244]

[53] Queiroz TS, Rehem TCMSB, Stival MM, et al. How do old men take care of their own health in Primary Care? Rev Bras Enferm 2018; 71(Suppl. 1): 554-61.

[http://dx.doi.org/10.1590/0034-7167-2017-0131] [PMID: 29562011]

[54] Rosu MB, Oliffe JL, Kelly MT. Nurse Practitioners and Men's Primary Health Care. Am J Men Health 2017; 11(5): 1501-11. [http://dx.doi.org/10.1177/1557988315617721] [PMID: 26614446]

[55] Santos KCD, Fonseca DFD, Oliveira PP, Duarte AGS, Melo JMA, Souza RS. Men's health care: construction and validation of a tool for nursing consultation. Rev Bras Enferm 2020; 73(3): e20190013.

[http://dx.doi.org/10.1590/0034-7167-2019-0013] [PMID: 32321139]

[56] Teixeira BBS, Cruz SPL. Attention to men's health: analysis of its resistance in seeking health services. Rev Cubana Nurse 2016; 32: 4.

[57] Silva ANE, Silva SAD, Silva ARVD, Araújo TME, Rebouças CBA, Nogueira LT. Primary care assessment from a male population perspective. Rev Bras Enferm 2018; 71(2): 236-43.

[http://dx.doi.org/10.1590/0034-7167-2016-0651] [PMID: 29412278]

[58] Ferreira DS, Teixeira E, Brown DO, et al. Content validation of an educational technology about men's Health. Rev Baiana Sick 2020; 34: e36344.

[http://dx.doi.org/10.18471/rbe.v34.36344]

[59] Batista BD, Andrade ME, Gadelha MMT, Silva JMA, Fernandes PKRS, Fernandes MC. Men's speeches on access to health in Primary Care. Rev baiana sick 2019; 33: e29268.

[http://dx.doi.org/10.18471/rbe.v33.29268]

This is an open access article distributed under the terms of the Creative Commons Attribution 4.0 International Public License (CC-BY 4.0), a copy of which is available at: https://creativecommons.org/licenses/by/4.0/legalcode. This license permits unrestricted use, distribution, and reproduction in any medium, provided the original author and source are credited. 